\title{
Contagion of Sovereign Debt Crises: The "Financial Crisis" Spill-Over from Greece to Cyprus in 2013. Empirical Evidence and Possible Conclusions
}

\author{
Frederic Florian Hans-Joachim Fiedler \\ Faculty of Business and Economics, Technical University Dresden, Germany \\ *Corresponding author: Fiedler FFHJ, Faculty of Business and Economics, Technical University Dresden, Germany, Tel: +4917624700201; E-mail: \\ frederic.fiedler@mailbox.tu-dresden.de
}

Received Date: Jul 20, 2018; Accepted Date: Aug 01, 2018; Published Date: Aug 07, 2018

Copyright: (C) 2018 Fiedler FFHJ, This is an open-access article distributed under the terms of the Creative Commons Attribution License, which permits unrestricted use, distribution, and reproduction in any medium, provided the original author and source are credited.

\begin{abstract}
In 2013 the Greek financial crisis hit the small island of Cyprus hard when it spilled over from Greece, due to the strong economic, financial and intercultural interlink ages. Even though it is questionable, whether Cyprus has created its own distress or if mainly the International and European architecture of the financial markets is to be blamed, an unprecedented step has been introduced by the Troika, a bail-out bail-in requirement. Through conducting an extensive literature review this unprecedented tool in the European history is analyzed in theory and subsequently regarding the Cyprus relief. The findings suggest that both, generally and specifically regarding the Cypriot case, a bail-in has shown to be effective in reducing financing needs for the respective governments and creditors. Nevertheless, such a measure does not come without a price. Therefore, implications on deposit holders and citizens are regarded.
\end{abstract}

Keywords: Contagion; Sovereign debt crisis; Cyprus crisis; Bail-out; Bail-in

\section{Introduction}

Situated in the eastern Mediterranean Sea south of Turkey, Cyprus is one of the smallest countries in the EU, having joined the EU in 2004 [1]. Even though it may not have been on the radar of most people as something other than a sunny holiday destination, it attracted attention in 2013 when it was hit by the contagion effects of the Greek financial crises and requested a bail-out amounting to $€ 17 \mathrm{bn}$. from the EU. Considering the high level of globalization leading to great financial, market and economic interdependencies among countries worldwide, the contagion of market downturns and financial crises has become a widely discussed topic among academics, politicians and policy-makers. Research and discussions are revived every time a new financial crisis hits the global or regional economies such as the Asian financial crisis in 1997-1998, the Dotcom crash in 2001 or the US Subprime crisis in 2008 which subsequently spurred the development of the global financial crisis which could be felt worldwide [2]. Often, one of the most popular approaches to deal with such financial crises is bailing out the party in financial distress. While the term bail-out has already become general vocabulary, the term bail-in is rather unknown to the general audience. However, this is what happened in Cyprus. To receive a $€ 10 \mathrm{bn}$. bail-out from the European Union, the country had to come up with roughly $€ 5.8 \mathrm{bn}$. itself. This was done by hitting all bank deposits over $€ 100000$ with a $9.9 \%$ one-off levy and all others with $6.75 \%$ [3]. Even though this was a controversial decision in light of its effect on investor confidence and public reaction, it appears it has paid off. Today, Cyprus has recovered from its financial situation while having used only $€ 7.5 \mathrm{bn}$. of its rescue package [4]. This paper aims at examining the actions taken by the Cyprus government to deal with the contagion of the financial crisis, having spilled over from Greece and to evaluate them together with other possible actions.
The remainder of the paper is structured as follows: Initially, the concept of contagion of financial crises is elaborated on. Secondly, factors that contributed to the contagion of financial crises from Greece to Cyprus are discussed. Thirdly, the Cypriot aid package in terms of a bailout and bail-in are elaborated on. Fourthly, the current state of Cyprus, its economy and financial health is presented. The final sections summarize and discuss the findings of the paper.

\section{Contagion of Financial Crises}

One of the largest threats emanating from a financial crisis is its contagion to other countries and economies. While the term contagion can be originally found in the field of medicine and biology as the spillover of diseases from one entity to another, the concept of contagion regarding financial crises can be interpreted similarly. Claessens et al. define contagion as the transmission of market disturbances (usually on the downside) from one country to another and divide it conceptually into 2 categories. The first category can be labelled as fundamentals-based contagion [5]. Here, a spill-over occurs from normal interdependencies between market economies resulting from trade- and financial linkages. Countries are usually more vulnerable to contagion if investors know of close financial ties to another country suffering from financial difficulties [6]. The second category describes contagion occurring from non-observable changes in the macroeconomic environment and fundamentals, often resulting from the behavior of investors, financial panic, loss of confidence, etc. The behavior of investors is particularly relevant considering the effect of financial crises in one country on their level of risk aversion regarding their investments in another country having the same group of investors [7]. Increasing levels of risk aversion in response to financial losses due to financial crises in one country increase their incentives to withdraw investments from other countries with the same group of investors, eventually leading to the contagion of financial disturbances across country borders. 
Similarly, during the European banking crisis, increased levels of differentiation regarding their vulnerability to the contagion of financial distress between Eurozone-countries could be observed. Countries exhibiting greater deficiencies in their domestic financial sector were often required to pay greater spreads after the public support for distressed banks became known [8]. Thus, countries exhibiting lower growth prospects and higher debt burdens were particularly susceptible to being the next victim of the Eurozone financial crisis. While it appears to be a popular opinion that countries slipping into a financial crisis are often the makers of their own demise, due to high government deficits and debt burdens, inadequate regulation of the financial sector or policy decisions, it should be kept in mind that "for every reckless debtor, there is a reckless creditor" [9]. The Eurozone financial crisis highlights this interconnectivity. With southern European countries, such Portugal and Greece slipping into financial difficulties, the popular opinion in the rest of Europe was that these countries in financial distress were themselves to blame due to their past investment and policy decisions. However, preceding this situation, western European countries were just too willing to provide southern European countries with loans in order to accumulate export surpluses which turned their financial and economic situation even more fragile (ibid). Faced with the decision of an immediate financial crisis or the prospect of a likely financial crisis in the future, financially distressed governments are more likely to choose the latter. Regardless, the question of who is to blame in such a situation cannot be answered straightforwardly due to the strong financial interlinkages among countries. Today, with high rates of globalization and international interdependencies, country-lines are often blurred, and it is virtually impossible for a country to make policy and investment decisions in isolation, without being impacted by the decisions and behaviors of other countries.

Cyprus is not only strongly culturally but also economically and financially linked to Greece, with Greece being one of the islands' main import and export partners accounting for approximately $20.25 \%$ and $21.25 \%$, respectively, in 2012 [10]. This strong market-related linkage to Greece can be considered as one of the most important factors responsible for the contagion of the Greece financial crisis to Cyprus. The next section will discuss further factors that made Cyprus susceptible to the contagion of financial disturbances.

\section{The Cyprus Financial Crisis}

In 2012, after two of the islands major banks suffered combined losses of $€ 4.5 \mathrm{bn}$., Cyprus finally turned to the European Union requesting for an aid package amounting to $€ 17$ bn [3]. There were several factors that made Cyprus particularly susceptible to the contagion of financial distress by closely linked economies. The following section will discuss these factors in greater detail.

\section{Factors that contributed to the development of the financial crisis}

Large banking sector and heavy foreign direct investments (FDI): Even though being a small island, Cyprus' lax financial regulations have made it a prominent place for foreign direct investments, often of rather shady origin, leading to an investment volume of roughly $€ 176$ bn., almost 1050\% higher than its GDP in May 2010 [11]. In 2011, Cyprus was the preferred place for inward and outward direct investments of Russian investors amounting to \$ 128 mil. and \$ 122 mil. Figure 1, respectively [12]. The only slight difference in investments shows that the investments remained only shortly in
Cyprus, supporting the claim that the purpose of investments might be rather dodgy [13]. Under the assumption that investments were not made for long-term purposes, troubles in the banking sector would incentivize investors to withdraw their investments from Cyprus. Figure 1 shows that FDI from Russia decreased significantly after 2013.

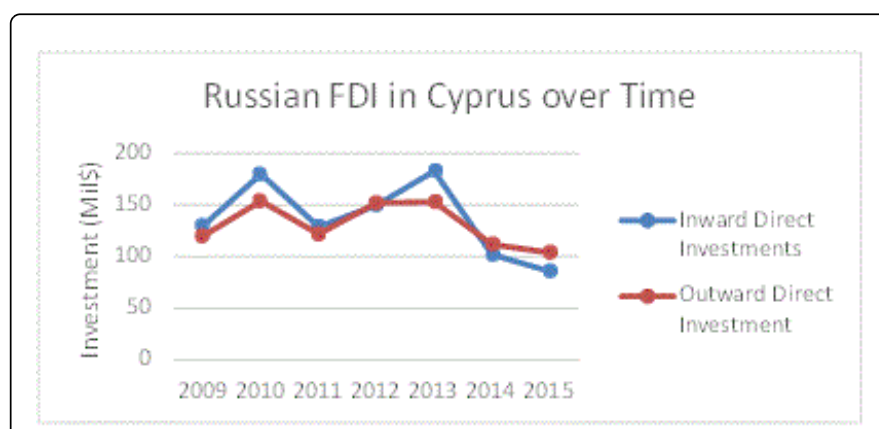

Figure 1: Russian FDI in cyprus over time, authors own (2017).

Similarly, Cyprus enjoyed great FDI from Greece with Greece being the single largest source of inward FDI in 2009, representing $24 \%$ of the level of FDI [14]. When financial distress started to emerge in the Greek economy, their investments in Cyprus reduced significantly Figure 2. With Greece investors extracting themselves (voluntarily or involuntarily) from the Cypriot financial sector, the risk exposure to other investors increased. Meanwhile, higher levels of risk exposure often incentivize investors to reconsider and eventually withdraw their investments with the aim of finding other investment opportunities that satisfy their requirements equally at similar levels of riskiness [7]. Thus, with Greek investors starting to withdraw their investments and defaulting on their bond payments, the signs of financial distress originating in Greece started to cascade into Cyprus.

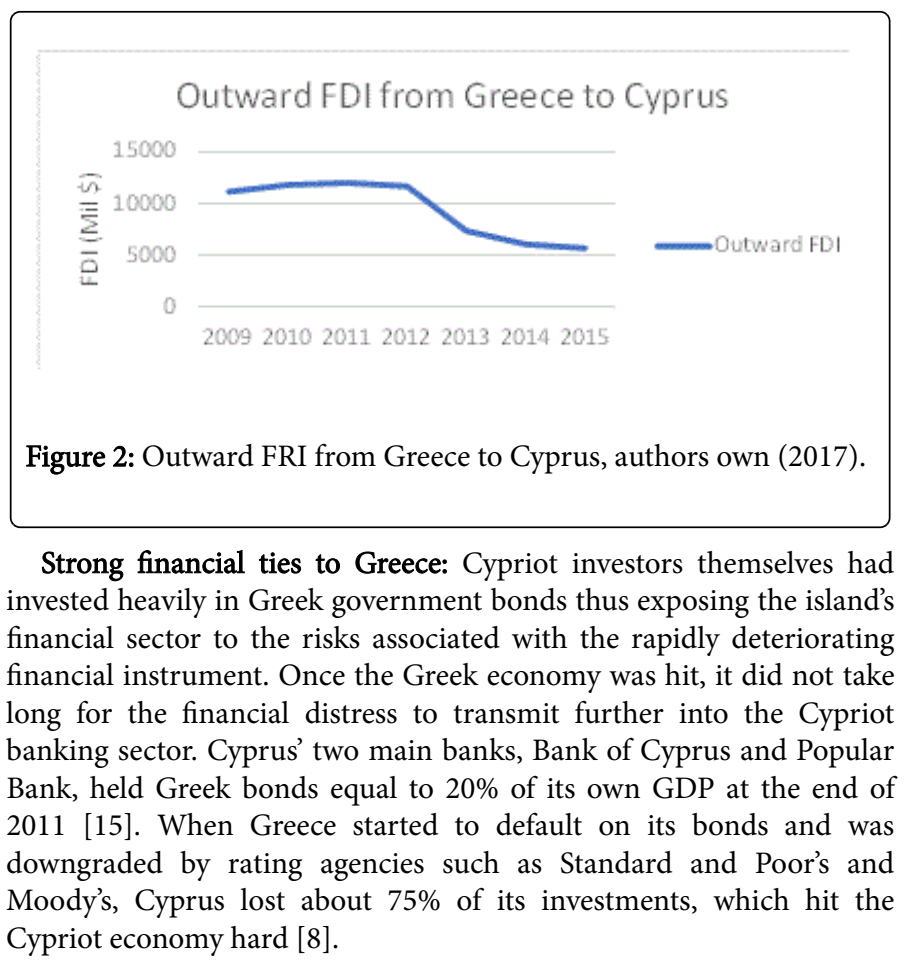

Moody's, Cyprus lost about $75 \%$ of its investments, which hit the Cypriot economy hard [8]. 
National debt and national deficit: Due to the financial and macroeconomic linkages between EU-member states, the European Commission and European Central Bank have developed the so-called convergence criteria in 1991, to ensure that member states can produce sound and sustainable public finance [16]. Government deficit and government debt as percent of GDP are used, respectively, as macroeconomic indicators. Meeting the convergence criteria is assumed to ensure convergence with other members of the EU area. Moody and Sandri show that during the Eurozone banking crisis, countries within the Eurozone were being differentiated based on their financial stability, measured by their growth prospects and debt burdens, with countries exhibiting higher levels of stress in their financial sector being more prone to being affected by the financial crisis [8].

Even though the convergence criteria stipulate a maximum government debt threshold of $60 \%$, Cyprus already exceeded this threshold when it joined the EU in 2004 featuring government debts of $70.93 \%$ of GDP [10]. This situation deteriorated severely over the years leading to government debts of approximately $90.61 \%$ in 2013 [1] Serving as an indicator for sustainable public finances, these debt levels highlight the instability of the Cypriot financial and public finance sector. Hence, even minor disruptions can have severe consequences.

Similarly, to measure sound public finance, the convergence criteria prescribe a maximum government deficit of $3 \%$ of GDP [16]. Again, already when joining the EU, Cyprus exceeded this threshold by $1.15 \%$. This value deteriorated further until, in 2013, it reached levels of $-5.64 \%[1]$.

With government debt and government deficit values far exceeding the threshold levels stipulated by the European Commission and European Central Bank, Cyprus was not able to withstand any financial disturbances. Thus, when Greece started to default on its bonds, which represented a large share of Cypriot investments, the government of Cyprus did not have any cushion to fall back on and the contagion of the financial crisis from Greece to Cyprus continued.

\section{The aid-package}

After the Popular Bank and the Bank of Cyprus had to report combined losses of approximately $€ 4.5$ bn., the government of Cyprus decided to seek assistance from the Eurozone in terms of an aid package, being the fifth Eurozone member to be saved from bankruptcy [17]. Followed by continuous downgrading of Cypriot government bonds by major rating agencies, such as Moody's, Standard and Poor's and Fitch, the island faced serious financial difficulties.

After intense and lengthy negotiations, the bail-out plan for Cyprus was finally set on March 16, 2013. Different to bail-out plans formulated for other struggling EU-member states, the Cypriot aidpackage included not only a bail-out package financed by the EU, but also a bail-in requirement.

Bail-out or bail-in: The initial amount to bail-out the island's financial sector was initially estimated to amount to approximately $€ 17$ bn. However, this request was denied by the European Union. Instead, to secure an aid package of $€ 10 \mathrm{bn}$., Cyprus was required to raise roughly $€ 5.8 \mathrm{bn}$. itself. While other countries in financial distress enjoyed several bail-out packages from the Eurozone, Cyprus was required to implement a bail-in plan in which bank deposits were hit with additional one-time taxes. Thus, savings exceeding $€ 100.000$ were hit with a $9.9 \%$ one-time tax levy and deposits below this amount were taxed with $6.5 \%$. Additionally, corporate tax rates, which were previously some of the lowest corporate tax rates within the EU, were raised from $10 \%$ to $12.5 \%$ [17]. Even though this safety-net tool is understandably not well perceived by private citizen and investors, bail-ins do have a stronger positive effect on the financial needs of failing banks and the resulting public finance costs than bail-outs do [18]. Being the most popular tool to handle the effects of financial crisis contagion and the spreading of systemic risks, the following section will discuss bail-outs. However, while bailouts can to handle the severity of Claessens a financial crisis, its effectiveness has historically been lower than anticipated which has led to the development of bail-ins [5]. Benczur et al. show that while bail-outs, i.e., increased capitalization, can reduce the financing needs of failing banks by $30 \%$, bail-ins perform even better by reducing financing needs by roughly $60 \%$ [18]. The effectiveness of bail-ins has been recognized by the European Central Bank, which has included this tool and its underlying logic into the newly published Basel III agreements [19].

Bail-out: Bail-outs have historically been a popular instrument to deal with financially distressed entities, including financial institutions, corporations and even countries, to reduce the systemic risks emanating from those entities and to handle the contagion of financial crises. It is not uncommon that foreign countries bail out a financially distressed country if there are strong financial ties such as high investments in government bonds and securities. In this case, if the indebted country starts to default on its bond payments, the foreign country may risk enormous losses which could affects its own financial sector and public finances. One prominent example includes the US bailout of Mexico in response to the Mexican currency crisis in 1995 [20]. With the financial crisis worsening in Mexico, it became more and more probable, that the government was going to default on its bond payments, threatening the USA with losses worth billions of dollars. The US government, in cooperation with the IMF, the Bank for international Settlements and private banks responded quickly by providing a bailout of more than $\$ 50 \mathrm{bn}$. Even though the bailout served its purpose and helped to stabilize the country's financial situation, it was heavily criticized by national and international politicians and financial experts for its eventual effect on other countries and their management of foreign debt and financial risk taking [21]. Regardless, bailouts became a common practice in response to financial actors in distress. Almost 15 years later, during the great recession of 2007-2008, the US government deployed government funds totaling $\$ 700 \mathrm{bn}$. to save failing financial institutions including Bear Stearns and AIG, which were deemed "too big to fail", implying that their bankruptcy would have consequences too severe for the economy as a whole to be allowed to go bankrupt. While proponents of this concept claim that bailing out distressed financial institutions is the optimal choice if the social costs of bankruptcy are too high, opponents stress the perils of excessive risktaking mentality, that can be induced by such policies since actors expect to be bailed out in case of failure [22,23].

While the majority of academic literature deals with the effects of bailouts on the national economy and financial sector, the recent financial crisis highlights the risks of cross-border contagion of financial crises. Acharya et al. investigate the link between bank bailouts and sovereign credit risks and find a mutually reinforcing link among these two factors [24]. If a distressed financial sector is bailed out, this increases the sovereign credit risk, which in turn weakend the financial sector even further. Eventually, the value of government guarantees and bond holdings decreases considerably which hurts the 
country's economy severly. Thus, even though bailouts may appear like a quick fix to counteract financial crises, the consequences of this policy must be evaluated thoroughly, including its effect on the country's sovereign credit risk and risk-taking mentality of relevant actors.

Bail-in: While in a bailout, the funding for the financing needs of a failing country or organization come from an external party, such as international organizations like the IMF, the European Central Bank or private financial institutions, Roubini and Sester also discuss the possibility of a bail-in. In the latter, the financing needs are not satisfied by increased capitalization from external sources but by raising these funds from within from the bank's creditors, usually by hitting unsecured deposits with tax levies based on a seniority ranking proposed by the European Central Bank [19,25]. The combination of bail-in and bailout is also possible, as it was the case in Cyprus and has since become part of the Basel III agreement published by the European Central Bank (ibid). Coeure argues that the introduction of bail-ins as part of a bail-out plan and the associated requirements for banks to have sufficient loss-absorbing capacity, i.e., sufficient capital, ensure that the risks of bankruptcy are reduced. Additionally, the associated regulations and measurement tools help to better monitor the risk behavior exhibited by banks [19]. Generally, the major aim of the new Basel III agreement is, to encourage banks and systemically important financial institutions to be more careful in their investment decisions, to eventually reduce the cross-exposure of banks and hence limit contagion possibilities.

Even though there appears to be evidence that bail-ins are generally advantageous in reducing the financial needs of the financially distressed country further than bailouts do, it does not come without pitfalls. Bail-ins is designed to shift the costs of bankruptcy from tax payers to the financial institutions' creditors, including deposit holders [18]. This possibility, however, can have great effects on the creditor's investment behavior. If investors fear, that their financial institution is on the verge of bankruptcy and is facing the implementation of a bailin plan, they are likely to withdraw their investments or deposits, fearing that they will otherwise have to carry the losses of the bail-in. This, however, weakens the financial institution even further, causing more investors to withdraw their investments. Thus, a self-reinforcing cycle develops, eventually leading to the bankruptcy of the institution. In light of the high level of interconnectivity of banks, other financial institutions and even businesses (through the role played by the payment and credit system, which is at the core of the economy), this is likely to cause other players in the field to run into financial trouble, exacerbating the financial crisis even further [9]. Thus, bail-ins can damage investor confidence severely, hurting the economy and the financial sector in the long-run. In the case of Cyprus, it is estimated that foreign investors withdrew approximately $18 \%$ of their investments in February 2013, fearing further taxes on their investments [26].

Hence, even though bail-ins are theoretically designed to shift the costs of financial distress from the taxpayer to the financial institutions' creditors, its effect on investor confidence, investor behavior and overall financial system should not be underestimated. Many opponents of the bail-in system argue that this tool merely redistributes part of the costs of financial distress without dampening its effect on the financial system or reducing its contagiousness [9]. Instead, greater levels of monitoring of systemically important financial institutions is required, coupled with stricter regulations regarding their capital ratios and separation of investment and commercial banking (ibid).

\section{Cyprus Today}

Today, Cyprus is celebrated as a success-story in how it overcame its financial crisis and exited its bail-out plan with utilizing only approximately $70 \%$ of the bail-out funds [4]. Even though the economy appears to be recovering with an economic growth rate of $1.75 \%$ in 2016 and the upgrading of government bonds by international rating agencies, the quick recovery did not come without costs [27]. One of the major factors enabling the small island to recover this quickly was the implementation of strict austerity measures including the restructuring of the healthcare and pension system and the public sector [4].

On paper, the quick recovery of Cyprus may appear impressive. However, the austerity measures implemented to enable the quick recovery still poses a threat to the Cypriot population. During the financial crisis, unemployment rates rose as high as $16.8 \%$ in 2013 and 2015 and still exceed the long-term average of $7.81 \%$ today by several percentage points [28]. Considering decreasing levels of household income, the healthcare reforms, including budget cuts and the introduction of co-payments, appear counterproductive considering the state of public health [29]. Especially in light of increasing levels of health problems emerging during financial crises, raising the barriers to access public health services can be expected to affect the population negatively in the long-term. Research suggests that austerity measures in the public health sector have negative effect on public health [30].

Similarly, despite the economy appearing to be recovering, outstanding banking loans classified as nonperforming are still high, inhibiting further growth opportunities [31]. Regardless, even though the bail-in policy cost many international investors losses amounting to millions of Euros, investor confidence has since improved considerably, leading to increases of FDI as high as 9.1\% in 2016 [32]. Further FDI is encouraged through increased speed and ease of issuing planning permissions, permits for joint tourist developments and already secured investments by large international investors, signaling high levels of investor confidence [33]. One of the most heavily criticized measures, however, has been the granting of citizenship based on investments in real estate, financial assets or companies operating in Cyprus exceeding $€ 3$ mil. [34]. Thus, even though Cyprus has recovered considerably since the outbreak of the financial crisis, its aftermath can still be felt throughout the economy.

\section{Discussion}

With ever increasing levels of interconnection between national financial markets and market economies, the importance of understanding the development, as well as contagion and containment of financial crises becomes ever more crucial. During the recent financial crisis, originating in the housing- CDO and CDS market in the USA, it did not take long for the financial crisis to swap over the Atlantic Ocean to Europe and to start affecting the local economies and financial markets. One of the main contributors to the contagion of financial crises are the interlink ages among financial markets and market economies among countries. These normal interlink ages have been termed fundamentals and, even though they can offer great advantages through, for example, cross-border trade, they can also be seen as unavoidable weakness if an important trading partner slips into financial distress [5]. This was the case for Cyprus, the small 
Mediterranean Island that was hit by a financial crisis in 2012/2013 due to its high exposure to the Greek economy. With the Bank of Cyprus and Popular Bank, the islands two largest and thus systemically important banks, having invested approximately $€ 4.7$ bn. in Greek government bonds in 2011, the island was inevitably due to be infected by the financial crisis. When Greece started to slip even further into financial failure and started to default on its bonds, Cyprus lost around $€ 3.5 \mathrm{bn}$. of its investments, approximating to $20 \%$ of its GDP [15].

There are, however, several factors that can influence the likelihood of a contagion of sovereign financial debt crises. Firstly, the countries featuring low growth prospects and government deficits are more susceptible to being the next victim of sovereign debt crises [8]. This is caused by the fact that those countries are often viewed as riskier thus, in case of financial distress, these countries have to pay greater sovereign spreads, weakening their economy even further. Without enough capital to cushion the fall, the country plummets deeper into financial troubles. In Cyprus, government debt and government deficit far exceeded the threshold levels stipulated by the EU convergence criteria, which aim at evaluating the financial strength of EU-member states. To counteract this problem, newly introduced regulations by the European Central Bank demand higher capital ratios to be in place.

A further aspect influencing the likelihood of contagion of sovereign debt crises relates to investor behavior and investor confidence. Research suggests that investors' individual investment decisions are not only influenced by the financial situation of one particular country or investment opportunity but also by the interlink ages among countries in their investment portfolio. Thus, if one country in the portfolio weakens considerably, the risks associated with a financially or economically linked country increases. Meanwhile, investors are incentivized to withdraw their investments [6,7]. This situation could be avoided if countries, or systemically important financial institutions, ensured that their investment portfolio was well diversified. Cyprus, however, was financially strongly linked to Greece. Considering the high risks associated with Greek government bonds, it could be speculated that Cypriot banks hoped to reap the high return rates associated with risky investments [15]. This investment behavior, however, should have been closely monitored by external investors who could have anticipated the danger of the situation and could have behaved accordingly. Regardless, once investor confidence is shattered, the financially distressed country or financial institution must implement incentives to encourage investors to invest again. Cyprus has implemented a series of measures, including citizenship by investment and facilitated real estate planning and construction.

In any case, once the financial crisis has been transmitted to a sovereign country, steps have to be taken to ease the situation and bring the country back on track. Historically, this has often been done through bailout agreements in which the funding for financial needs comes from external sources such as other countries or international organizations. Even though this tool can dampen the severity of financial distress and eventually help the country to recover from its situation, it is often criticized by politicians and the general public claiming that the burden of the financial crisis should not be carried by foreign taxpayers. Therefore, the European Central Bank has passed the Basel III agreement including the terms and conditions for a combined bail-in and bailout plan for financially distressed countries. I contrast to a bailout, in a bail-in, investors of unsecured deposits in the financially distressed country are required to share in on the costs of recovery by having their deposits hit by tax-levies to fund the bail-in. Despite the fact, that this has shown to help reduce the financial needs of the troubled country considerably, it can have a disastrous effect on investor confidence of foreign investors. In Cyprus, which was a preferred destination for Russian FDI, approximately $18 \%$ of foreign investments were withdrawn when news about the bailout-bail-in plan became known. To counteract further withdrawals, the country implemented capital controls, controlling the amounts to be transferred abroad. This cost investors losses amounting to millions of Euros, impacting their willingness to re-invest in the Cypriot banking sector.

Additionally, the quick recovery was also enabled through the implementation of severe austerity measures including pay-cuts and lay-offs in the public sector and the reformation of the health system. While this has saved the government great amounts of expenditures, it should be kept in mind that financial crises often result in decreasing household incomes. This, again, can influence the mental health of the population through increased levels of depression and anxiety. By increasing the barriers to public health services through, for example reduced insurance coverage and co-payments, infectious diseases and mental health problems can become a major problem [30]. Thus, even though austerity measures may help to spur the recovery of the financial state of the economy, its effect on the population should not be neglected. How this will affect Cyprus in the long-run still remains to be seen.

In light of the high level of globalization and the economic and financial linkages among countries, the contagion of financial crises can pose a major threat to economies around the globe. Even though some countries may be particularly vulnerable to the contagion of financial crises, due to their government debt and government deficit levels, a weak financial sector and their exposure to other countries' financial situation, the financial markets around the globe are so tightly interconnected that it is virtually impossible not to be affected in some way. Still, if not directly affected by the collapse of a sovereign financial market, aid packages to the distressed country often contain funding from external sources, tying in foreign taxpayers' money. To counteract this situation, bail-in plans have been proposed. While this, theoretically, makes the investors of the respective country accountable for the costs associated with a recovery, it should be kept in mind that the deterioration of a country's financial sector does not happen suddenly but develops over time. Hence, countries on the verge of a financial collapse often apply to wealthier countries for loans, who are mostly very willing to provide those in hope of accumulating export surpluses. Thus, instead of recommending caution and encouraging preemptive measures, it could be claimed that wealthier countries are often inclined to exploit the situation. The blame for a financial crisis, however, should not be assigned to the financially distressed country alone. Given the high level of interconnectivity among countries, it appears that new regulations and tools aiming at preventing the contagion of sovereign debt crises should not only be developed on a country basis but rather deal with the international architecture of financial markets and economies.

\section{Conclusion}

The aim of this paper was to discuss factors affecting the contagion of sovereign financial debt crises and to evaluate possible subsequent actions such as bail-outs and bail-ins, by an example of the Cyprus financial crisis of 2012/2013. In Cyprus, due to its high financial exposure to the Greek economy and high government debts and government deficits, the island was unable to avert the contagion of the sovereign financial debt crisis. Following other EU-member states, the 
country eventually applied for an aid package from the EU. However, in contrast to other countries, which received bailout funds totaling billions of Euros, the Cypriot agreement also contained a bail-in plan, in which unsecured deposits were hit with a $9.9 \%$ tax levy, thus shifting the costs of recovery from taxpayers to investors. While the country recovered quickly and without exhausting the complete bailout funds, the economy and the financial sector still have a long way to go. Even though bail-ins in some cases might be superior to bail-outs, in a way, that they reduce the costs to taxpayers and shift this burden to holders of unsecured deposits, this measure can have an adverse effect on the subsequent investment behavior of international investors. But not only the investors are to be seen, also the local population suffered severe financial losses due to the crisis. Apart from ruthless speculators, mostly the public was hit hard by the bail-in measures. This paper also gave evidence, that a bail-in can only be effective, if executed quickly and silently avoiding the investors to flee the country (which intensifies the downturn of the financial market then) and that the high degree of interlink ages of the global financial markets and market economies should never be underestimated in terms of the effects of uncertainty on global investments. Nevertheless, in any case investors' confidence is shattered when they are forced to stay in with their money through capital controls, like it happened in Cyprus, while the bail-in was performed. It will take decades for Cyprus to regain full confidence of investors. Finally, one myth has been deconstructed: That the EU won't ever let one member down.

\section{References}

1. Eubusiness (2017) European Union/Member Countries/Cypruy.

2. Anderson S (2017) A history of the past 40 years in financial crises Int Financ Rev (IFR 2000 Issue Supplement).

3. Eubusiness (2013b) Cyprus: key stages in island's financial crisis.

4. Ellyatt $\mathrm{H}$ (2016) $\mathrm{CNBC} /$ That was quick! Cyprus exits bailout with cash to spare.

5. Claessens A Dornbusch R Park Y (2013) Contagion: Why Crises Spread and How This Can Be Stopped In: Claessens S Forbes $\mathrm{K}$ editors. International Financing Contagion Springer Science and Business Media, New York, pp: 19-41.

6. Kaminsky G, Lizondo S, Reinhart C (1998) Leading indicators of Currency Crises IMF Staff.

7. Goldstein I, Pauzner A (2004) Contagion of self-fulfilling crises due to diversification of investment portfolios. J Econ Theory 119: 151-183.

8. Moody A, Sandri D (2012) The eurozone crisis: how banks and sovereigns came to be joined at the hip. Economic Policy, 27: 119-230.

9. Grauwe DP (2013) The New Bail-in Doctrine: A recipe for banking crises and depression in the Eurozone CEPS.

10. WITS (2017) World Integrated Trade solutions/Country Profile/CYP.

11. IMF (2010) Cyprus: Selected Issues IMF. International monetary fund, Washington, DC, USA.
12. IMF (2011) Coordinated Direct Investment Survey.

13. Kar D, Freitas S (2013) Russia: Illicit Financial Flows and the Underground Economy. Global Financial Integrity.

14. Mcit (2010) Foreign Investments in Cyprus. Department or Trade Ministry of Commerce Industry and Tourism, India.

15. Foxman S (2013) Quartz/ The truth behind Cyprus's bank catastrophe Cypriot banks are really just Greek banks in dsguise.

16. EC (2017) Convergence criteria for joining.

17. Eubusiness (2013a) Cyprus: key stages in island's financial crisis.

18. Benczur P Cannas G Cariboni J Girolamo DF Maccaferri S Giudici M (2017) Evaluating the effectiveness of the new EU regulatory framework: A farewell to bail-out? J Financ Stab 33: 207-223.

19. Coeure B (2017) The implications of bail-in rules for bank activity and stability.

20. Covey R (1996) Adventures in the Zone of Twilight: Separation of Powers and National Economic Security in the Mexican Bailout Yale L J 105: 1311.

21. Musacchio A (2012) Mexico's Financial Crisis of 1994-1995. Harvard Business School.

22. Freixas X (1999) Optimal Bail-Out Policy Conditionality and Constructive Ambiguity. SSRN.

23. Woods T (2009) Meltdown: A Free-Market Look at Why the Stock Market Collapsed the EconomyTanked and the Government Bailout Will Make Things Worse. Regnery Publishing, New York.

24. Acharya V Drechsler I Schnabl P (2014) A Pyrrhic Victory? Bank Bailouts and Sovereign Credit Risk J Financ 69: 2689-2739.

25. Roubini N, Sester B (2004) Bailouts or Bail-Ins?: Responding to Financial Crises in Emerging Economies. Peterson Institute for International Economics, Washington, DC.

26. Kaplan M (2013) Playing with Fire: The Cyprus Banking Crisis. Review of Banking \& Financial Law 33: 41-49.

27. Smith H, Treanor J (2016) Cyprus crisis and the bank that came back from the brink.

28. Ycharts (2017) Indicators.

29. Petrou P, Vandoros S (2017) Healthcare Reforms in Cyprus 2013-2017: Does the crisis mark the end of the healthcare sector as we know it? Health Policy, 122: 75-80.

30. Karanikolos M, Mladovsky P, Cyclus J, Thomson S, Basu S, et al. (2013) Financial crisis Austerity and health in Europe. The Lancet, London, 381: 1323-1331.

31. Ewing J (2015) As Cyprus Recovers from Banking Crisis Deep Scars Remain International Business.

32. Cyprus P (2017) Foreign Direct Investment.

33. Kyriakides N (2015) Deloitte: The Cyprus Economy: Two Years after the financial Crisis.

34. Farolfi A, Pegg D, Orphanides S (2017) The billionaires investing in Cyprus in exchange for EU passports. 